\title{
Response of bacterial grazing rates to experimental manipulation of an Antarctic coastal nanoflagellate community
}

\author{
Dolors Vaqué $^{1, *}$, Susana Agustí ${ }^{2}$, Carlos M. Duarte ${ }^{2}$ \\ ${ }^{1}$ Institut de Ciències del Mar de Barcelona-CMIMA, CSIC, Departament de Biologia Marina i Oceanografia, \\ Passeig Marítim de la Barceloneta, 37-49, 08003 Barcelona, Catalunya, Spain \\ ${ }^{2}$ IMEDEA (CSIC-UIB), Institut Mediterrani d'Estudis Avançats, Miquel Marquès, 21, 07190 Esporles, Mallorca, \\ Illes Balears, Spain
}

\begin{abstract}
We examined changes of bacterial losses related to heterotrophic nanoflagellate (HNF) size distribution in late spring/early summer (1998/1999) using 9 grazing experiments in a coastal Antarctic area (Johnson's Dock, Livingston Island, Bransfield Sector). Water samples were subjected to size fractionation through 50 and $5 \mu \mathrm{m}$ pore sizes to obtain a truncation of the microbial food web. In each fraction, we estimated bacterial loss rates and abundance and biomass of HNF grouped into 4 size classes $(\leq 2,2$ to 5,5 to 10,10 to $20 \mu \mathrm{m})$. We also investigated whether grazing on bacteria was mainly due to HNF, and which HNF size class had a major impact on bacteria. We expected that in the $50 \mu \mathrm{m}$ fraction, large protists (ciliates, dinoflagellates) would prey preferentially on nanoprotists and relieve bacterial pressure from HNF. Bacterial grazing rates were estimated by disappearance of fluorescently labeled bacteria over $24 \mathrm{~h}$. These showed similar values in both experimental treatments, although they were slightly higher for the $50 \mu \mathrm{m}$ fraction. Average grazing rates were $4.8 \times$ $10^{5} \pm 3.6 \times 10^{5}$ cells ml ${ }^{-1} \mathrm{~d}^{-1}$ in the $5 \mu \mathrm{m}$ treatment and $6.9 \times 10^{5} \pm 3.2 \times 10^{5}$ cells ml ${ }^{-1} \mathrm{~d}^{-1}$ for the $50 \mu \mathrm{m}$ fraction. In the $5 \mu \mathrm{m}$ fraction, HNF abundance (integrated over $24 \mathrm{~h}, \mathrm{HNFi}$ ) and bacterial grazing rates were significantly related. The best relationship was obtained with the smallest HNFi size classes (from $\leq 2$ and 2 to $5 \mu \mathrm{m}$ ). In the $50 \mu \mathrm{m}$ fraction, no relationships were found between bacterial loss rate and both total HNFi and any HNFi size class in terms of abundance and biomass. However, microozooplankton was negatively related to total bacteria and both HNFi abundance and biomass. The major contributor to this negative relationship was the HNFi size classes from $\leq 2$ and 2 to $5 \mu \mathrm{m}$. Consequently, and against our expectations, large protists contributed to microbial food-web complexity by masking carbon fluxes from bacteria to $\mathrm{HNF}$, and by feeding on both bacteria and nanoprotists.
\end{abstract}

KEY WORDS: Antarctica - Johnson's Dock - Bacteria - Heterotrophic nanoflagellate size · Phagotrophic $\cdot$ Ciliates $\cdot$ Dinoflagellates $\cdot$ Grazing Resale or republication not permitted without written consent of the publisher

\section{INTRODUCTION}

It is becoming increasingly apparent that the microbial food web plays an important role in the carbon flow of the Southern Ocean (Bird \& Karl 1999, Anderson \& Rivkin 2002). However, there is still a paucity of estimates of grazing rates on bacteria, as well as a lack of detailed examination of the nature of the grazer community. In particular, while heterotrophic nanoflagellates (HNF) are considered to be the main predators of bacteria (Pace 1988, Sherr \& Sherr 1994), the components of this community that dominate grazing rates are highly variable. For instance, small HNF (1 to $3 \mu \mathrm{m}$ ) have been shown to be the main bacterial grazers from temperate and warm oligotrophic to cold systems, such as the Mediterranean Sea (Wikner \& Hagström 1988, 
Christaki et al. 2001), the Pacific Ocean near Hawaii (Calbet et al. 2001) and the Central Arctic Ocean (Sherr et al. 1997). However, there is also evidence that chonaoflagellates from 4 to $15 \mu \mathrm{m}$ in size are the main grazers in the Southern Ocean (Leakey et al. 1996, Becquevort 1997). Some HNFs can use alternative prey, such as dissolved organic matter (Marchant \& Scott 1993), as well as pico- and nanoeukaryotic cells of a similar size (Sanders 1991, Peters et al. 1998, Calbet et al. 2001, Sherr \& Sherr 2002). HNFs can also engage in complex trophic interactions with larger protists such as ciliates and phagotrophic dinoflagellates (Capriulo et al. 1991, Lynn \& Montagnes 1991). The structure of the protist community can, therefore, greatly affect bacterial grazing rates.

Here we examine bacterial grazing rates and their response to experimental manipulation (size fractionation) of the protist community in an Antarctic coastal ecosystem. The study was conducted in a shallow coastal area in Johnson's Dock, a sheltered bay receiving glacial melt water, adjacent to the Spanish Antarctic Base (Livingston Island, Shetland Islands, Bransfield Sector, Antarctica). Nine experiments examining the effects of size manipulation of HNFs on bacterial grazing rates were conducted in late spring/early summer 1998/1999. These experiments tested whether grazing on bacteria is mainly due to HNF, and what size fraction of HNF had the greatest impact on bacteria in the presence or absence of larger predators. We hypothesized that organisms such as ciliates and phagotrophic dinoflagellates should preferentially prey on nanoprotists and relieve bacterial pressure from HNF grazing when present.

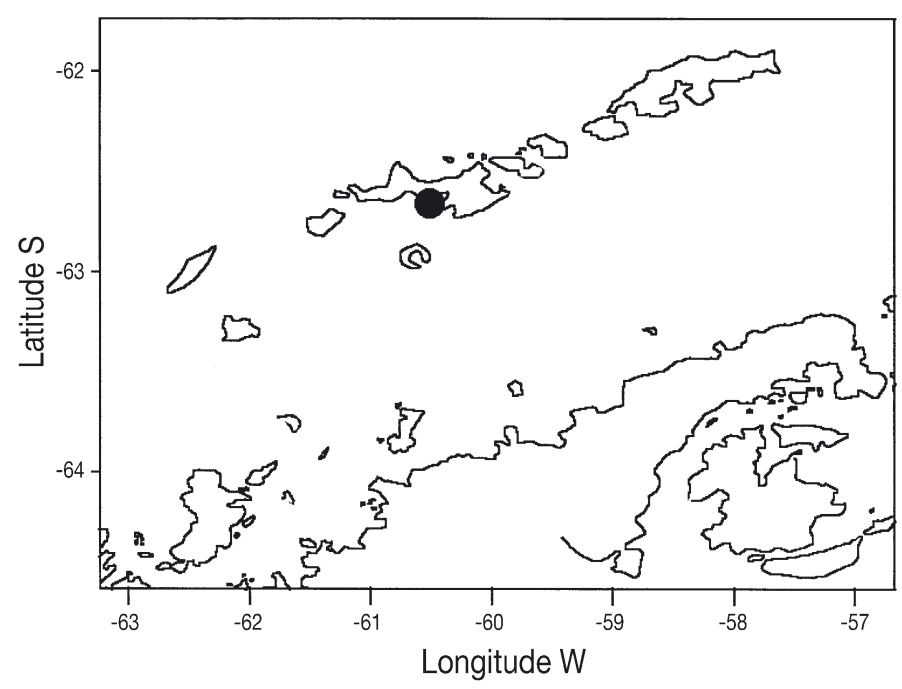

Fig. 1. Sampling site

), Johnson's Dock, Livingston Island (Antarctica)

\section{MATERIALS AND METHODS}

Study site and sampling. The study was conducted in Johnson's Dock $\left(62^{\circ} 39.576^{\prime} \mathrm{S}, 60^{\circ} 22.408^{\prime} \mathrm{W}\right)$, Livingston Island, Shetland Islands, Bransfield Sector, Antarctica (Fig. 1) from December 10, 1998, to January 2, 1999. Samples were collected from a small boat 2 or 3 times a week at a fixed station within the bay $(25 \mathrm{~m}$ depth). On each sampling date a vertical profile of temperature and salinity was obtained with an Andera T-S probe, and water transparency was determined with a $25 \mathrm{~cm}$ diameter Secchi disc. We collected 301 integrated water samples encompassing the photic layer (0 to $5 \mathrm{~m}$ ). Using a flexible tube $(7 \mathrm{~m}$ long, $10 \mathrm{~cm}$ diameter, with a weight at the end attached to a rope) submerged between 0 and $5 \mathrm{~m}$ depth, water was emptied into a $30 \mathrm{l}$ carboy. Water was kept in the dark during transportation to the laboratory (15 min away from the sampling site). In the laboratory, the samples were processed to determine nutrient and chl a concentrations, bacterial, nanoplankton, and ciliate abundance and biomass, and grazing experiments were conducted.

Nutrients. Samples for inorganic nutrient determinations were taken in plastic bottles from the $30 \mathrm{l}$ carboy at the end of each grazing experiment and kept frozen until analysis. Inorganic phosphorus nitrate, nitrite and ammonium were analyzed with an Evolution II (Alliance Instruments) autoanalyzer following Hansen $\&$ Coroleff (1983).

Chl a concentration. A variable water volume (100 to $250 \mathrm{ml}$, depending on phytoplankton biomass) was filtered through $0.45 \mu \mathrm{m}$-diameter cellulose acetate Millipore filters for spectrofluorometric analysis of chl a (Parsons et al. 1984). The filters were kept refrigerated for ca. $24 \mathrm{~h}$ in the dark while pigments were extracted in $90 \%$ acetone. Fluorescence was measured following extraction in a Shimadzu 1501 spectrofluorometer calibrated with pure chl a (Sigma).

Bacterial, flagellate and ciliate abundance and biomass. Subsamples of $100 \mathrm{ml}$ were preserved with glutaraldehyde (1\% final concentration) for bacteria and nanoflagellate counts. Duplicate subsamples of 5 and $10 \mathrm{ml}$ for bacteria nanoflagellate counts were filtered through 0.2 and $0.6 \mu \mathrm{m}$ polycarbonate filters, respectively, and stained with DAPI (4,6-diamidino-2phenylindole, Porter \& Feig 1980) at a final concentration of $5 \mu \mathrm{g} \mathrm{ml}^{-1}$ (Sieracki et al. 1985). The abundance of these microorganisms was determined by epifluorescence (Nikon Optiphot) microscopy. Nanoflagellates showing red-orange fluorescence (when illuminated with blue light) and/or plastidic structures were considered as phototrophic forms (phototrophic nanoflagellates PNF), while colorless nanoflagellates were counted as heterotrophic (HNF). Mixotrophic nanoflagellates could not be reliably identified. Bacterial size 
was determined from the linear dimension of approximately 300 cells from 3 samples corresponding to the beginning (December 10, 1998), middle (December 15, 1998) and end (January 2, 1999) of the study period. We used an image analysis system attached to the microscope, using the NIH-image software as described in detail in Massana et al. (1997) to derive bacterial cell-size distributions. Bacterial biomass was calculated using the carbon-to-volume relationship derived by Norland (1993) from the data of Simon \& Azam (1989): pg C cell ${ }^{-1}=0.12 \times V^{0.7}$, where $V$ is volume of bacteria in $\mu^{3}$ cell $^{-1}$.

Nanoflagellate size was determined by measuring lengths and widths of 50 to 150 cells (HNF plus PNF) per sample under an epifluorescence microscope with a calibrated ocular micrometer. HNF were grouped into 4 size classes: $\leq 2,2$ to 5,5 to 10 and 10 to $20 \mu \mathrm{m}$. Cell volumes were estimated using the most similar geometrical figure, and the carbon content estimated

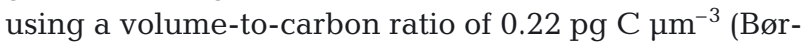
sheim \& Bratbak 1987).

Ciliates and large dinoflagellates, such as Gyrodinium, were enumerated in 11 samples preserved in a $1 \%$ final concentration of acidic Lugol's solution. This concentration is at the lower end ( 0.6 to $20 \%$ ) of the scales reported by several authors (Harris et al. 2000, and references therein). High concentrations of acid Lugol's solution (10 to $20 \%$, Stoecker et al. 1994, Boyd et al. 1995) have been recommended to avoid cell losses. Therefore, the ciliate concentrations in this study may have been underestimated. A $100 \mathrm{ml}$ subsample was placed in $100 \mathrm{ml}$ sedimentation chambers for $48 \mathrm{~h}$ before enumeration at $400 \times$ magnification, using an inverted microscope (Zeiss). Average ciliate and dinoflagellate cell sizes were determined after measuring the lengths and widths of 30 to 100 cells; these values were then used to calculate the cell volume by approximation to the most similar geometric form. The carbon content of ciliates was estimated using the equations described in Menden-Deuer \& Lessard (2000) that were derived from Putt \& Stoecker's (1989) study for aloricate ciliates $\left(\mathrm{pg} \mathrm{C} \mathrm{mm}^{-3}=0.230 \times V^{0.984}\right.$, where $V$ is cell volume in $\mu^{3}$ ), and from the studies on tintinnids by Verity \& Langdon (1984) and Beers \& Stewart (1967) $\left(\mathrm{pg} \mathrm{C} \mu^{3}=0.679 \times V^{0.841}\right)$. Finally, dinoflagellate carbon content was estimated using Menden-Deuer \& Lessard's (2000) C: $V$ relationship for planktonic protist: $\operatorname{pg} \mathrm{C} \mu \mathrm{m}^{3}=0.216 \times V^{0.939}$.

Grazing experiments. Estimates of grazing on bacteria by protists (HNF, ciliates, dinoflagellates) were based on the disappearance over time of fluorescently labeled bacteria (FLB) (Brevundimonas diminuta, formerly Pseudomonas diminuta, strain provided by 'La Colección Española de Cultivos tipo', Burjassot, Valencia, Spain) following the procedure of Pace et al. (1990) and Vazquez-Dominguez et al. (1999). Grazing on bacteria was determined 2 or 3 times a week. In each determination, 71 subsamples were drawn, 21 were filtered through $0.8 \mu \mathrm{m}$ polycarbonate filters (to exclude bacterial predators) to be used as controls, and 21 were filtered through $5 \mu \mathrm{m}$ net mesh to eliminate HNF predators (e.g. microzooplankton). Finally, the last 31 were filtered through a $50 \mu \mathrm{m}$ net mesh to exclude larger predators (e.g. naupliae). FLB were added to 11 duplicate samples ( 10 to $20 \%$ of ambient bacterial concentration) of each water fraction. The average volume of labeled $B$. diminuta was similar to the average volume of the ambient bacteria $\left(0.066 \pm 0.003 \mathrm{um}^{3} \mathrm{cell}^{-1}\right.$, range: 0.064 and $0.071 \mu^{3}$ cell $^{-1}$ ). The samples were incubated for $24 \mathrm{~h}$ in a $1 \mathrm{~m}^{3}$ incubation tank with running seawater to maintain in situ temperature and light conditions. The abundance of $B$. diminuta, natural bacteria, HNF and PNF was determined at the beginning of the experiment and at $24 \mathrm{~h}$, and ciliate and Gyrodinium abundance and size were determined only in the $50 \mu \mathrm{m}$ fraction at the beginning of the experiment. The number and biomass of bacteria removed were derived using the mathematical model of Salat \& Marrasé (1994). Grazing rates $(G)$ on bacteria between 0 and $24 \mathrm{~h}$ were calculated as an exponential process: $G=a / g \times\left(\operatorname{bac}_{0} \times \mathrm{e}^{a\left[t_{1}-t_{0}\right]}-\mathrm{bac}_{0}\right)$, where $a$ is the net specific bacterial growth rate $\left(\mathrm{d}^{-1}\right), g$ is the specific bacterial grazing rate $\left(\mathrm{d}^{-1}\right)$, and $\left(\mathrm{bac}_{0} \times \mathrm{e}^{\mathrm{a}\left[\mathrm{t}_{1}-t_{0}\right]}-\mathrm{bac}_{0}\right)$ is the net bacterial production (NBP) between 0 and $24 \mathrm{~h}$, with $t_{1}, t_{0}$ as the final and initial experimental times, respectively. Gross bacterial production $(\mathrm{PB}, \mu \mathrm{g}$ $\mathrm{C}^{-1} \mathrm{~d}^{-1}$ ) was calculated as the sum of $G$ and NBP. These calculations are based on the conservative assumption that all losses of bacteria during the incubations were due to grazing by protists.

To compare changes of HNF and bacterial abundance or biomass with bacterial losses over $24 \mathrm{~h}$, we integrated $\mathrm{HNF}\left(\mathrm{HNF}_{\mathrm{i}}\right)$ or bacterial abundance and biomass within this period:

$\mathrm{HNF}_{\mathrm{i}}\left(t_{1}, t_{0}\right)=\mathrm{HNF}_{0} \times \mathrm{e}^{\left(b \times 0.5\left(t_{1}-t_{0}\right)\right.}$, where $b$ is the net specific HNF growth rate $\left(\mathrm{d}^{-1}\right)$, and $\mathrm{HNF}_{0}$ is the HNF abundance or biomass at the beginning of the experiment. We carried out the same procedure for bacterial abundance and biomass.

\section{RESULTS}

\section{Physico-chemical and biological parameters}

The waters in Johnson's Dock had a milky aspect (Secchi disk depth $\sim 1.5 \mathrm{~m}$ ) due to the glacial flour, a colloid of quartz crystals delivered from the adjacent glaciers (Azetsu-Scott \& Syvitski 1999), which extended far offshore of Livingston Island, as revealed by transects 
conducted aboard the Spanish RV 'Hespérides' (Agustí \& Duarte 2000). Surface salinity reached low values due to the fresh glacial melt waters, and temperature remained relatively uniform during the study period (Table 1). Nutrient concentrations were maintained at very high values $\left(\mathrm{NO}_{3}: 22.2\right.$ to $31.4 \mu \mathrm{M} ; \mathrm{NO}_{2}: 0.2$ to $0.3 \mu \mathrm{M}_{i} \mathrm{NH}_{4}$ : 1.1 to $2.5 \mu \mathrm{M}_{i} \mathrm{PO}_{4}: 1.3$ to $1.6 \mu \mathrm{M}_{i} \mathrm{SiO}_{4}$ : 54.1 to $63.4 \mu \mathrm{M})$ throughout the study. Chl a concentrations ranged from 0.3 to $2.2 \mu \mathrm{g} \mathrm{l}^{-1}$ (average: $1.5 \pm 0.6 \mu \mathrm{g}$ $\mathrm{l}^{-1}$, Table 1). The autotrophic community was dominated by PNF, including free-living Phaeocystis (3 to $5 \mu \mathrm{m}, 14 \pm 8 \%$ of PNF biomass) and Cryptomonas (10 to
$12 \mu \mathrm{m})$, which represented $66 \pm 15 \%$ of the PNF biomass (Table 1$)$, and very few diatoms $\left(<50\right.$ cells $\left.\mathrm{l}^{-1}\right)$. Bacteria and HNF dominated heterotrophic biomass, with choanoflagellates representing only $16 \pm 7 \%$ of the HNF biomass (Table 1). The microbial community fluctuated during the study period (Fig. 2). Minimal and maxumal abundance and cell size are shown in Table 2. Nanoflagellates (HNF and PNF) tended to be smaller in size as their abundance increased (Table 2). Temporal changes of bacteria, HNF and PNF net growth rates, using 5 and $50 \mu \mathrm{m}$-screened fractions, revealed that after $24 \mathrm{~h}$ incubation, bacteria and HNF abundance (in

Table 1. Summary of temperature (Temp), salinity (Sal), chl a concentration (Chl), and biomass of total phototrophic nanoflagellates (PNF), Phaeocystis (Phaeo.), Cryptomonas (Crypto.), bacterioplankton (Bact.), total heterotrophic nanoflagellates (HNF) and choanoflagellate (Choano.), and microzooplankton (ciliates: Cil; Gyrodinium: Gyr) during the study period. nd: not detected; -: not determined

\begin{tabular}{|c|c|c|c|c|c|c|c|c|c|c|c|}
\hline $\begin{array}{l}\text { Date } \\
\text { (dd/mm/yy) }\end{array}$ & $\begin{array}{l}\text { Temp } \\
\left({ }^{\circ} \mathrm{C}\right)\end{array}$ & $\begin{array}{l}\text { Sal } \\
(\% \circ)\end{array}$ & $\begin{array}{c}\text { Chl } \\
\left(\mu \mathrm{g} \mathrm{l}^{-1}\right)\end{array}$ & $\begin{array}{c}\text { PNF } \\
\left(\mu \mathrm{Cl}^{-1}\right)\end{array}$ & $\begin{array}{c}\text { Phaeo. } \\
\left(\mu \mathrm{Cl}^{-1}\right)\end{array}$ & $\begin{array}{l}\text { Crypto. } \\
\left(\mu \mathrm{C} \mathrm{Cl}^{-1}\right)\end{array}$ & $\begin{array}{c}\text { Bact. } \\
\left(\mu \mathrm{g} \mathrm{Cl}^{-1}\right)\end{array}$ & $\begin{array}{c}\mathrm{HNF} \\
\left(\mu \mathrm{Cl}^{-1}\right)\end{array}$ & $\begin{array}{l}\text { Choano. } \\
\left(\mu \mathrm{g} \mathrm{Cl}^{-1}\right)\end{array}$ & $\begin{array}{c}\mathrm{Cil} \\
\left(\mu \mathrm{Cl}^{-1}\right)\end{array}$ & $\begin{array}{c}G y r \\
\left(\mu \mathrm{Cl}^{-1}\right)\end{array}$ \\
\hline $10 / 12 / 98$ & 0.9 & - & 1.0 & 18.3 & - & - & 23.5 & 3.5 & 1.1 & 5.1 & 1.34 \\
\hline $12 / 12 / 98$ & 0.8 & 33.37 & 0.3 & 49.9 & 5.1 & 23.6 & 22.3 & 8.2 & 1.3 & 0.8 & 0.47 \\
\hline $15 / 12 / 98$ & 0.6 & 33.17 & 2.0 & 68.4 & 5.3 & 50.1 & 28.1 & 8.3 & 1.1 & 1.0 & 1.76 \\
\hline $18 / 12 / 98$ & 0.7 & 33.35 & 1.5 & 57.8 & 4.7 & 37.7 & 21.4 & 18.2 & 1.3 & 5.5 & 6.20 \\
\hline $21 / 12 / 98$ & 0.5 & 32.24 & 1.2 & 46.2 & 6.1 & 24.2 & 22.3 & 9.2 & 0.9 & 1.4 & 0.12 \\
\hline $24 / 12 / 98$ & 0.9 & 32.89 & 1.5 & 91.4 & 6.7 & 85.6 & 46.5 & 7.8 & 0.9 & nd & 0.04 \\
\hline $27 / 12 / 98$ & 1.1 & 33.33 & 2.2 & 35.8 & 4.5 & 26.9 & 24.3 & 10.1 & 1.4 & 2.4 & 0.03 \\
\hline 29/12/98 & 1.2 & 33.31 & 2.1 & 47.8 & 10.8 & 22.8 & 39.2 & 6.7 & 1.3 & 1.1 & 0.73 \\
\hline 02/01/99 & 0.4 & 33.68 & 1.3 & 34.5 & 11.3 & 24.6 & 31.6 & 6.4 & 1.6 & 0.6 & 0.54 \\
\hline
\end{tabular}

Table 2. Minimal (upper line) and maximal (lower line) values of abundance or cell volume (prefix ' $\mathrm{V}$ ') of different microorganisms (bacteria: Bact; heterotrophic and phototrophic nanoflagellates: HNF and PNF) over all experiments in both treatments ( 5 and $50 \mu \mathrm{m}$ ) at Time 0 and after $24 \mathrm{~h}$ incubations (represented as 0 or 24 after experiment name)

\begin{tabular}{|c|c|c|c|c|c|c|c|c|c|c|c|}
\hline \multicolumn{6}{|c|}{$5 \mu \mathrm{m}$ treatment } & \multicolumn{6}{|c|}{$50 \mu \mathrm{m}$ treatment } \\
\hline \multirow[t]{2}{*}{$\begin{array}{l}\text { Expt } \\
\text { no. }\end{array}$} & $\begin{array}{l}\text { Date } \\
\text { (dd/mm/yy) }\end{array}$ & Variable & \multicolumn{2}{|c|}{$\begin{array}{l}\text { Expt Date } \\
\text { no. }(\mathrm{dd} / \mathrm{mm} / \mathrm{yy})\end{array}$} & Variable & \multicolumn{2}{|c|}{ no. $(\mathrm{dd} / \mathrm{mm} / \mathrm{yy})$} & Variable & \multicolumn{2}{|c|}{ no. (dd/mm/yy) } & Variable \\
\hline & & $\begin{array}{c}\text { Bact }_{\mathbf{0}} \\
\left(10^{6} \text { cells } \mathrm{ml}^{-1}\right)\end{array}$ & & & $\begin{array}{c}\text { Bact }_{24} \\
\left(10^{6}{\left.\text { cells } \mathrm{ml}^{-1}\right)}^{-1}\right.\end{array}$ & & & $\begin{array}{c}\text { Bact }_{\mathbf{0}} \\
\left(10^{6} \text { cells ml }^{-1}\right)\end{array}$ & & & $\begin{array}{c}\text { Bact }_{24} \\
\left(10^{6} \text { cells ml }^{-1}\right)\end{array}$ \\
\hline 9 & 02/01/99 & 1.08 & 4 & $18 / 12 / 98$ & 1.37 & 4 & 18/12/98 & 1.29 & 3 & 15/12/98 & 1.28 \\
\hline \multirow[t]{2}{*}{6} & $24 / 12 / 98$ & 2.36 & 5 & $21 / 12 / 98$ & 2.65 & 6 & $24 / 12 / 98$ & 2.81 & 5 & $21 / 12 / 98$ & 2.70 \\
\hline & & $\begin{array}{c}\mathbf{H N F}_{\mathbf{0}} \\
\left(10^{3} \text { cells ml }^{-1}\right)\end{array}$ & & & $\begin{array}{c}\mathbf{H N F}_{24} \\
\left(10^{3} \text { cells ml}^{-1}\right)\end{array}$ & & & $\begin{array}{c}\mathbf{H N F}_{\mathbf{0}} \\
\left(10^{3} \text { cells ml }^{-1}\right)\end{array}$ & & & $\begin{array}{c}\mathbf{H N F}_{24} \\
\left(10^{3} \text { cells ml }^{-1}\right)\end{array}$ \\
\hline 1 & $10 / 12 / 98$ & 1.20 & 1 & $10 / 12 / 98$ & 1.31 & 9 & 02/01/99 & 1.23 & 4 & $18 / 12 / 98$ & 0.54 \\
\hline \multirow[t]{2}{*}{6} & $24 / 12 / 98$ & 2.67 & 6 & $24 / 12 / 98$ & 2.52 & 6 & $24 / 12 / 98$ & 3.33 & 6 & $24 / 12 / 98$ & 2.23 \\
\hline & & $\begin{array}{c}\mathbf{V H N F}_{\mathbf{0}} \\
\left(\mu \mathrm{m}^{3} \mathrm{cell}^{-1}\right)\end{array}$ & & & $\begin{array}{c}\mathrm{VHNF}_{24} \\
\left(\mu \mathrm{m}^{3} \mathrm{cell}^{-1}\right)\end{array}$ & & & $\begin{array}{c}\mathbf{V H N F}_{\mathbf{0}} \\
\left(\mu \mathrm{m}^{3} \mathrm{cell}^{-1}\right)\end{array}$ & & & $\begin{array}{c}\mathbf{V H N F}_{24} \\
\left(\mu \mathrm{m}^{3} \mathrm{cell}^{-1}\right)\end{array}$ \\
\hline 6 & $24 / 12 / 98$ & 7.02 & 7 & $27 / 12 / 98$ & 8.09 & 6 & $24 / 12 / 98$ & 7.02 & 5 & $21 / 12 / 98$ & 4.78 \\
\hline \multirow[t]{2}{*}{1} & $10 / 12 / 98$ & 17.99 & 1 & 10/12/98 & 32.88 & 2 & $12 / 12 / 98$ & 38.22 & 2 & $12 / 12 / 98$ & 58.13 \\
\hline & & $\begin{array}{c}\mathbf{P N F}_{\mathbf{0}} \\
\left(10^{3} \text { cells } \mathrm{ml}^{-1}\right)\end{array}$ & & & $\begin{array}{c}\mathbf{P N F}_{24} \\
\left(10^{3}{\left.\text { cells } \mathrm{ml}^{-1}\right)}^{-1}\right.\end{array}$ & & & $\begin{array}{c}\mathbf{P N F}_{\mathbf{0}} \\
\left(10^{3} \text { cells ml }{ }^{-1}\right)\end{array}$ & & & $\begin{array}{c}\mathbf{P N F}_{24} \\
\left(10^{3} \text { cells ml }^{-1}\right)\end{array}$ \\
\hline 1 & $10 / 12 / 98$ & 1.79 & 1 & $10 / 12 / 98$ & 1.51 & 1 & 10/12/98 & 2.37 & 4 & 18/12/98 & 1.13 \\
\hline \multirow[t]{2}{*}{8} & 29/12/98 & 4.84 & 3 & 15/12/98 & 4.28 & 8 & 29/12/98 & 4.34 & 3 & $15 / 12 / 98$ & 5.39 \\
\hline & & $\begin{array}{c}\mathbf{V P N F}_{\mathbf{0}} \\
\left(\mu \mathrm{m}^{3} \mathrm{cell}^{-1}\right)\end{array}$ & & & $\begin{array}{c}\mathbf{V P N F}_{24} \\
\left(\mu \mathrm{m}^{3} \mathrm{cell}^{-1}\right)\end{array}$ & & & $\begin{array}{c}\mathbf{V P N F}_{\mathbf{0}} \\
\left(\mu \mathrm{m}^{3} \text { cell }^{-1}\right)\end{array}$ & & & $\begin{array}{c}\mathbf{V P N F}_{24} \\
\left(\mu \mathrm{m}^{3} \mathrm{cell}^{-1}\right)\end{array}$ \\
\hline 8 & 29/12/98 & 40.64 & 8 & 29/12/98 & 19.49 & 5 & $21 / 12 / 98$ & 35.10 & 8 & 29/12/98 & 18.94 \\
\hline 2 & $12 / 12 / 98$ & 88.56 & 9 & 02/01/99 & 158.42 & 6 & $24 / 12 / 98$ & 105.63 & 6 & 24/12/98 & 96.14 \\
\hline
\end{tabular}


most of cases) and PNF abundance (in 4 out of 9 cases) were lower in the $50 \mu \mathrm{m}$ than in the $5 \mu \mathrm{m}$ treatment (Fig. 2A-F). This decay observed in the $50 \mu \mathrm{m}$-screened fraction was likely due to predatory losses imposed by ciliates and the phagotrophic Gyrodinium (Fig. 2G). Ciliate abundance varied from undetectable to $1.74 \times$ $10^{3}$ cells $^{-1}$, and Gyrodinium abundance from $0.11 \times 10^{3}$ to $2.11 \times 10^{3}$ cells $^{-1}$ (Table 2, Fig. 2). The assemblage of oligotrich (Strombidium acutum, S. conicum, Laboea sp.) plus naked choreotrich (Strobilidium sp.) ciliates was always present, except for the last sampling day, comprising between 13 and $86 \%$ of the total abundance and between 3 and $92 \%$ of biomass (when detectable). The second most important group was the Scuticociliates, which were present on 6 occasions, and varied between 9 and $71 \%$ of abundance and 3 and $86 \%$ of biomass. The phototrophic Mesodinium sp. was also fairly abundant at the end of the study period (up to $60 \%$ of total abundance), but in terms of biomass only achieved $39 \%$ of total ciliate biomass on the 5 occasions
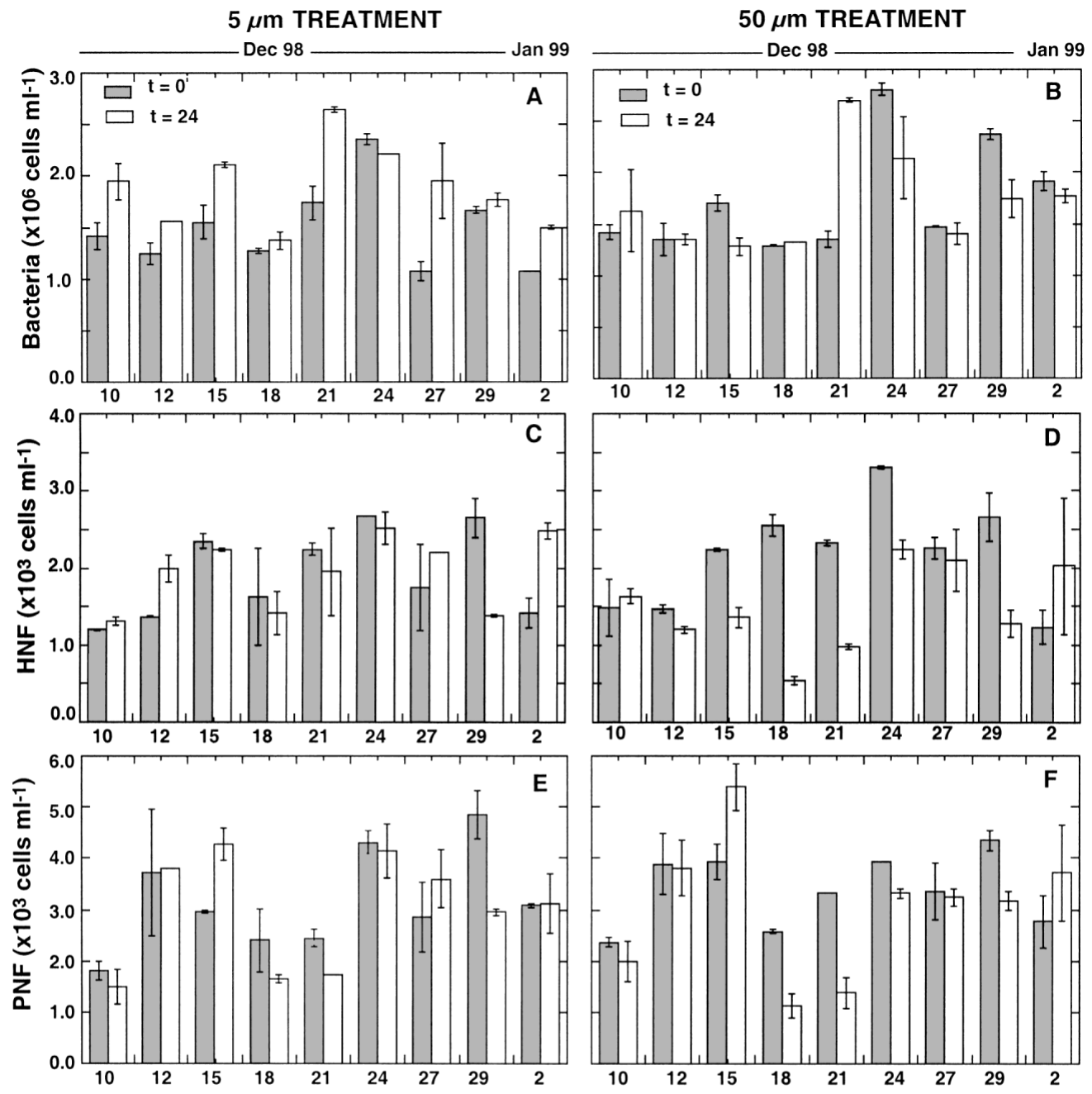

Date

Fig. 2. Evolution of $(A, B)$ bacterial, $(C, D)$ heterotrophic nanoflagellate (HNF) and $(\mathrm{E}, \mathrm{F})$ phototrophic nanoflagellate (PNF) abundance during the study period in both treatments $(5$ and $50 \mu \mathrm{m})$ at Time 0 and after $24 \mathrm{~h}$ incubations ( $t=$ 0 and $t=24$, respectively). (G) Evolution of phagotrophic ciliate and dinoflagellate abundance in the $50 \mu \mathrm{m}$ treatment over the sampling dates

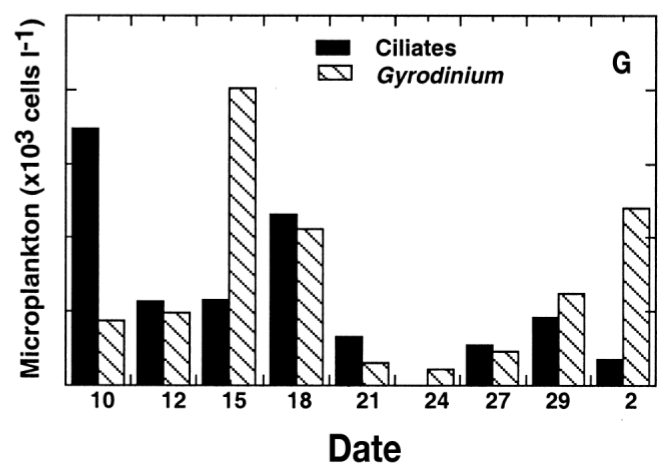


when it was present. Ciliates included in other groups (mainly vorticellids) were present on 4 occasions, and varied between 5 and $27 \%$ of abundance and 3 and $78 \%$ of biomass. Finally, tintinnids were the least predominant (only found 3 times), varying in abundance between 16 and $28 \%$ and 4 and $26 \%$ of biomass.

\section{Dynamics of nanoflagellate size classes}

The 2 to $5 \mu \mathrm{m}$ size class dominated HNF abundance, both in the $5 \mu \mathrm{m}$-screened fraction $(53.7 \pm 5.9 \%)$ and in the $50 \mu \mathrm{m}$-screened fraction $(59.2 \pm 3.2 \%)$, followed by the size class of $\leq 2 \mu \mathrm{m}$ ( $5 \mu \mathrm{m}$-screened fraction: $37.6 \pm$ $5.6 \% ; 50 \mu \mathrm{m}$-screened fraction: $30.9 \pm 3.3 \%$ ). HNF abundance in the 5 to $10 \mu \mathrm{m}$ size class was much lower (5 $\mu \mathrm{m}$-screened fraction: $8.5 \pm 0.9 \%$, and $50 \mu \mathrm{m}$ - screened fraction: $9.5 \pm 1.9 \%)$, and was negligible in the 10 to $20 \mu \mathrm{m}$ size class ( $5 \mu \mathrm{m}$-screened fraction: $0.2 \pm$ $0.2 \% ; 50 \mu \mathrm{m}$-screened fraction: $0.4 \pm 0.3 \%$ ). HNF abundance decreased after $24 \mathrm{~h}$, mostly in the $50 \mu \mathrm{m}$ screened fraction, with this decline being higher for the 2 to $5 \mu \mathrm{m}$ HNF size class than for the $\leq 2 \mu \mathrm{m}$ one (Fig. 3). HNF net growth rates were higher in most cases for all size classes in the $5 \mu \mathrm{m}$-screened fraction than in the $50 \mu \mathrm{m}$-screened fraction (Fig. 4). The same trend applied to PNF.

\section{Grazing rates}

Live controls were performed for each experimental set up, whereby water was filtered through $0.8 \mu \mathrm{m}$ to remove bacterial predators and ensure that the dis-
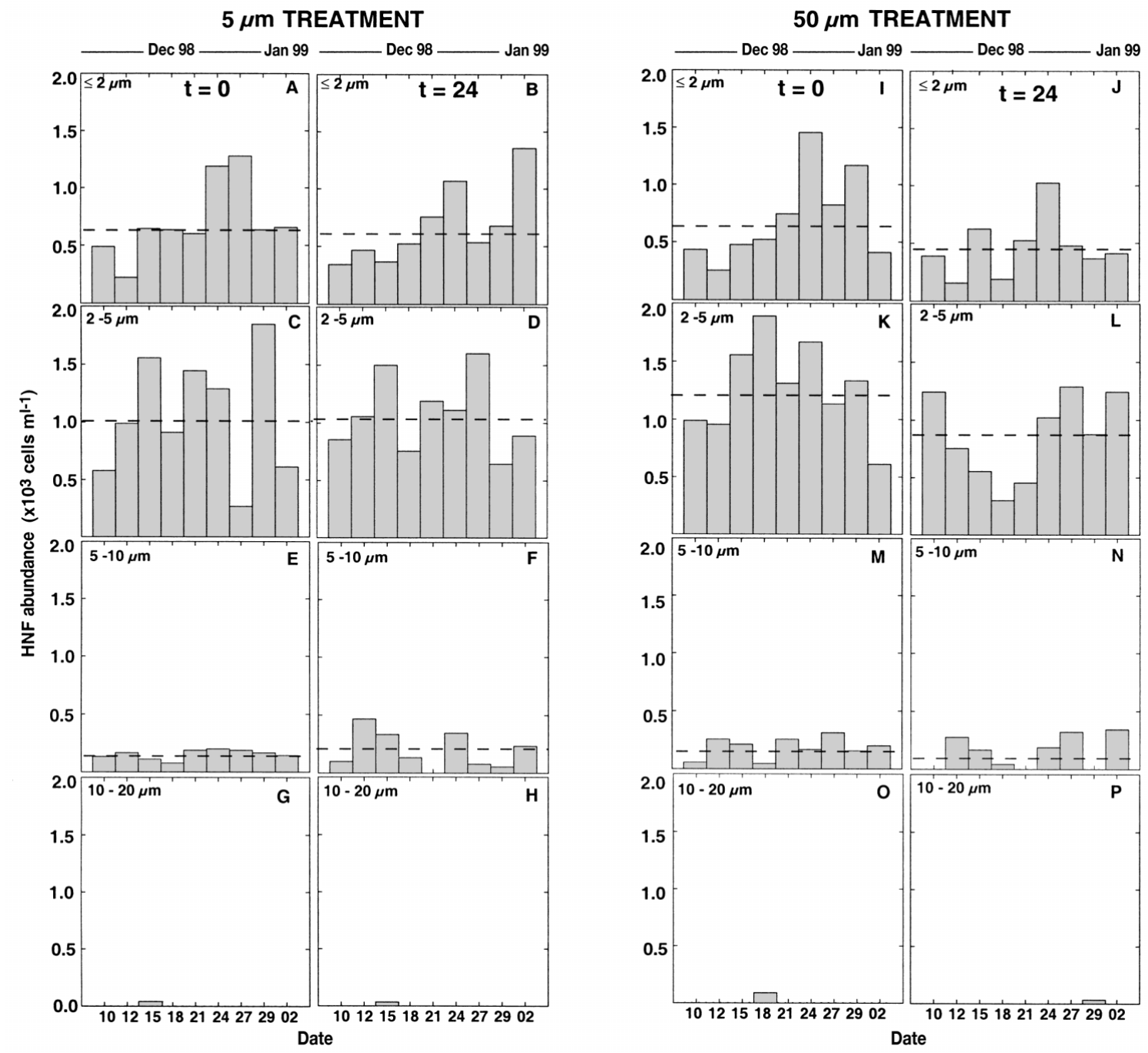

Fig. 3. Changes of heterotrophic nanoflagellate (HNF) size classes during the study period at the Time 0 and at $24 \mathrm{~h}$ into the grazing experiments $(t=0$ and $t=24$, respectively). Dashed lines indicate average abundance for each size class 


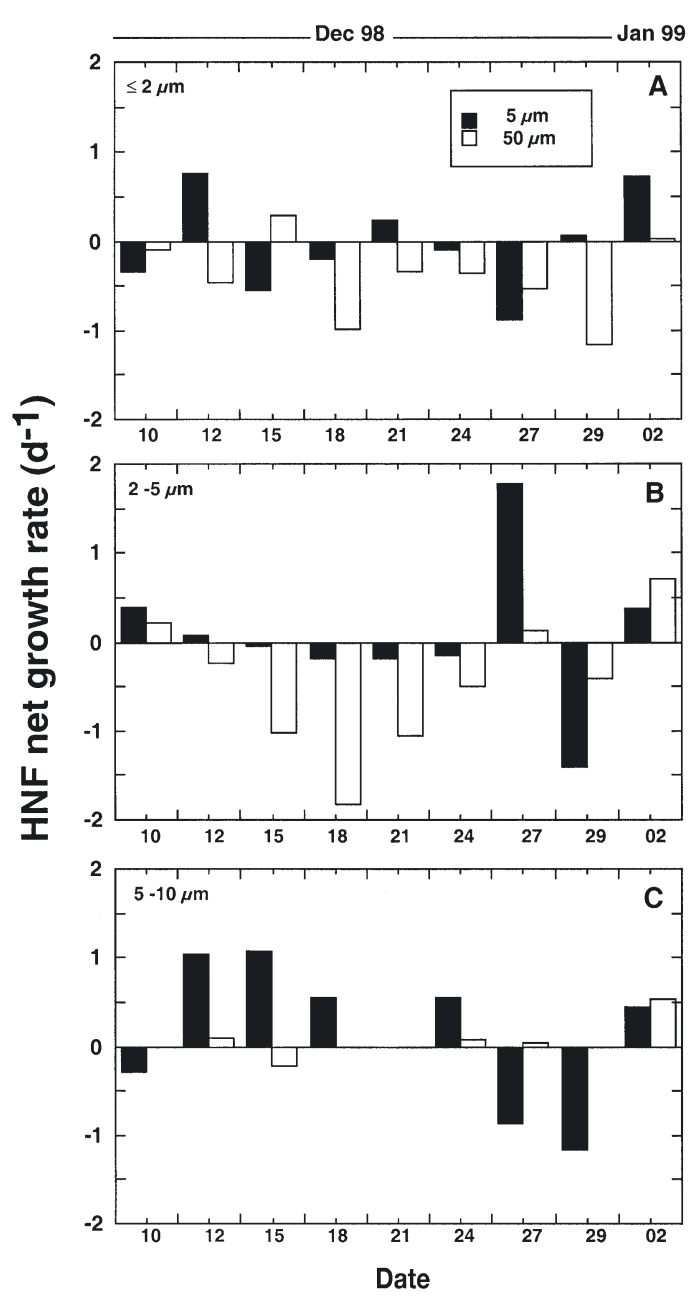

Fig. 4. Changes of net heterotrophic nanoflagellate (HNF) growth rates for each size class during the study period

appearance of FLBs was due only to grazers; 3 out of 9 experiments showed detectable, yet negligible, bacterial losses. Specific grazing rates $\left(\mathrm{d}^{-1}\right)$ differed significantly for various size fractions (ANOVA: $\mathrm{n}=$ $27, F=14.61, \mathrm{p}=0.0001)$. Grazing rates declined as the filtration cut-off size declined from $50 \mu \mathrm{m}$ (average: $0.41 \pm 0.17 \mathrm{~d}^{-1}$ ) to $5 \mu \mathrm{m}$ (average: $0.27 \pm 0.18 \mathrm{~d}^{-1}$ ) and $0.8 \mu \mathrm{m}\left(0.03 \pm 0.058 \mathrm{~d}^{-1}\right)$. The losses in the $0.8 \mu \mathrm{m}$ treatments were due to a few HNF that went through the $0.8 \mu \mathrm{m}$ filters, as confirmed by microscopic examination of the samples.

The average bacterivory rate was slightly higher for the $50 \mu \mathrm{m}\left(6.9 \times 10^{5} \pm 3.2 \times 10^{5}\right.$ cells ml ${ }^{-1} \mathrm{~d}^{-1}, 11.6 \pm$ $\left.5.36 \mu \mathrm{g} \mathrm{C}^{-1} \mathrm{~d}^{-1}\right)$ than for $5 \mu \mathrm{m}\left(4.8 \times 10^{5} \pm 3.6 \times 10^{5}\right.$ cells $\mathrm{ml}^{-1} \mathrm{~d}^{-1}, 8.1 \pm 6.1 \mu \mathrm{g} \mathrm{C} \mathrm{l}^{-1} \mathrm{~d}^{-1}$ ) screened samples (Fig. 5A,C). These losses accounted for the removal of the full bacterial production in the $50 \mu \mathrm{m}$-screened treatment (102 $\pm 45 \%$ of bacterial production) and half of the bacterial production $(53 \pm 33 \%$ ) for the $5 \mu \mathrm{m}$ screened treatment.
$5 \mu \mathrm{m}$-screened fraction

Bacterial grazing rates were significantly related to HNFi abundance, but not to their biomass (Table 3). The combined abundance of the $\leq 2$ and 2 to $5 \mu \mathrm{m}$ HNFi fractions accounted for most ( $75 \%$, Table 3$)$ of the variance in grazing rates among the different experiments. Similar results were obtained between HNFi ( $\leq 2$ and 2 to $5 \mu \mathrm{m}$ ) biomass and consumed bacterial carbon and bacterial grazing rates (Table 3, Fig. $5 \mathrm{~A}, \mathrm{~B}$ ). Regression analyses suggest the 2 to $5 \mu \mathrm{m}$ HNFi size class to be most closely associated with grazing rates (Table 3). Larger HNFi (5 to $10 \mu \mathrm{m}$ ) were not significantly related with grazing or with other nanoprotist cells (PNF or HNF), neither in terms of carbon nor in number of cells. However, a significant negative relationship was found between the net growth rate of 2 to $5 \mu \mathrm{m} \mathrm{HNF}$ and that of 5 to $10 \mu \mathrm{m}$ HNF (Table 3), suggesting either predatory or competitive interactions within the HNF assemblage.

$50 \mu \mathrm{m}$-screened fraction

No relationships were found between bacterial loss rates and total HNFi or any HNFi size class in terms of either their abundance (data not shown) or biomass (Fig. 5C,D). Microozooplankton (ciliates and dinoflagellates) abundance was negatively related to total bacteria and HNFi abundance, as well as bacterial biomass (Table 3). The main contributors to this negative relationship in terms of abundance was the HNFi size classes $\leq 2$ and 2 to $5 \mu \mathrm{m}$ (Table 3). Contrary to our expectations, the presence of phagotrophic ciliates and dinoflagellates (e.g. Gyrodinium) (Table 1, Fig. 2) increased the food-web complexity, masking the tight relationship between HNFi and grazing rates on bacteria observed in the $5 \mu \mathrm{m}$ treatment.

\section{DISCUSSION}

\section{Methodological considerations}

Fractionation

The size-fractionation approach has specific weaknesses. The fractionation step may cause cell damage and enrichment of dissolved organic matter (Landry 1994, Gasol \& Moran 1999), and exclude large predators, which would affect nutrient regenerators (e.g. Güde 1986). For instance, the higher bacterial growth detected in the $5 \mu \mathrm{m}$-screened fraction on December 15 and 27 (Figs. 2 \& 5) could be attributable to an extra supply of organic matter in this treatment due to cell 

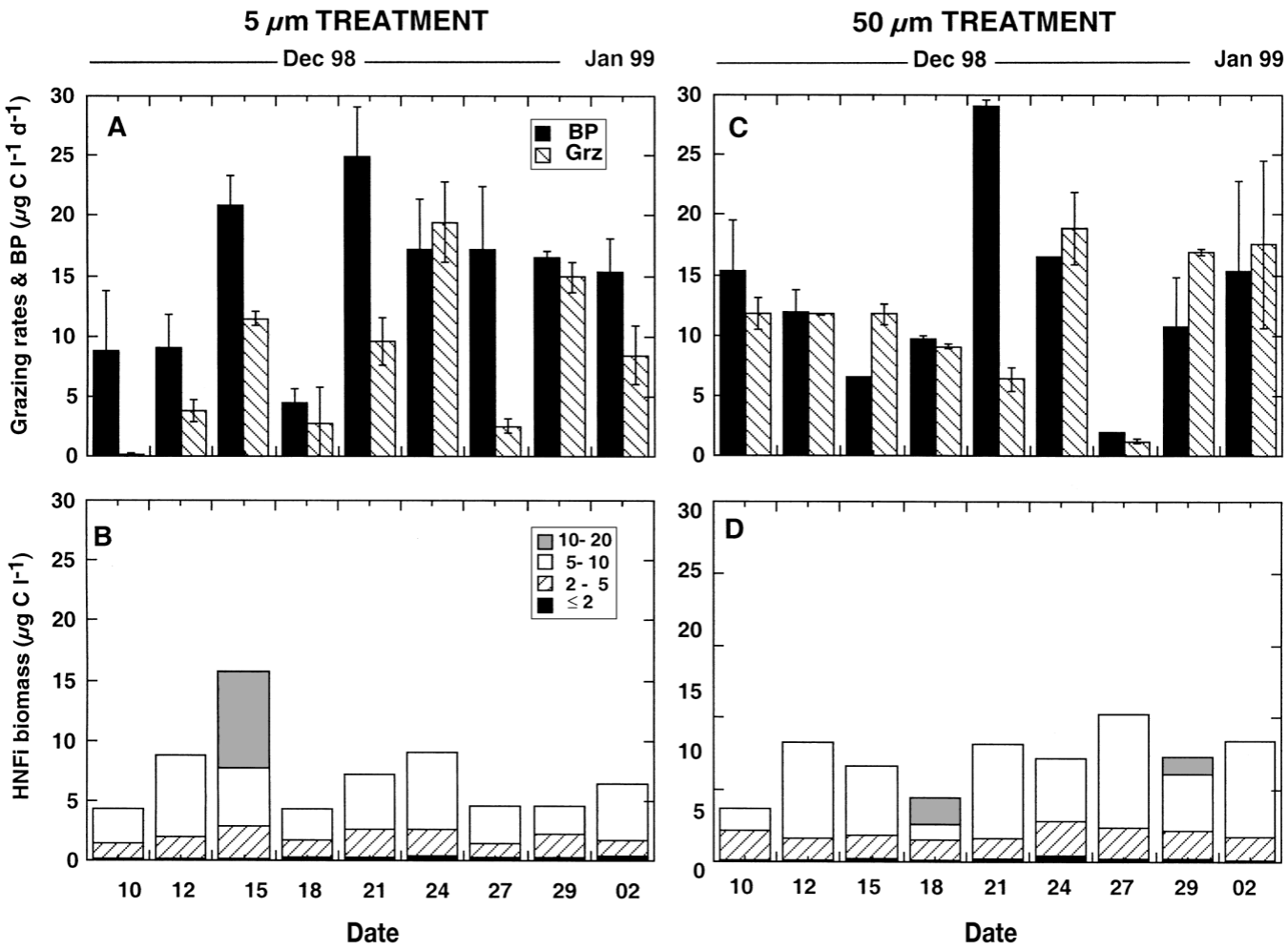

Fig. 5. Evolution of $(A, C)$ bacterial carbon losses (Grz) and bacterial production (BP) and (B,D) HNF abundance integrated over $24 \mathrm{~h}\left(\mathrm{HNF}_{\mathrm{i}}\right)$ for the different size classes $(\mu \mathrm{m})$ during the study period. Grz: grazing rate

Table 3. Relationship between grazing rates on bacteria and heterotrophic nanoflagellates (HNF) integrated over $24 \mathrm{~h}$; net HNF growth rate of 2 to 5 and 5 to $10 \mu \mathrm{m}$ size classes; microzooplankton and bacteria or HNF integrated over $24 \mathrm{~h}$. Values of different variables were $\log$ transformed. Dep.: dependent; $a$ : intercept; $b$ : slope; Ind.: independent. Bold values: relationships with statistically significant level ( $\mathrm{p}$ 0.05). GRZ: grazing rates (abundance of bacterial cells ingested $\mathrm{ml}^{-1} \mathrm{~d}^{-1}$ ); BGRZ: grazing rates (biomass $[\mu \mathrm{g}]$ of bacterial carbon ingested $\left.\mathrm{l}^{-1} \mathrm{~d}^{-1}\right)_{i} \mathrm{HNFi}$ : integrated HNF abundance (cells ml ${ }^{-1}$ ); BHNFi: integrated HNF biomass ( $\mu$ g HNF carbon $\mathrm{l}^{-1}$ ), numbers in parentheses refer to the size classes of HNFi; NHNFG: net HNF growth rate $\left(\mathrm{d}^{-1}\right)$; $\mathrm{MICRO}$ : microzooplankton (ciliates + dinoflagellates); BNi: integrated bacterial abundance (cells $\left.\mathrm{ml}^{-1}\right)_{;} \mathrm{BBi}$ : integrated bacterial biomass

\begin{tabular}{|c|c|c|c|c|c|c|c|}
\hline Dep. variable & $a$ & $b$ & Ind. variable & $\mathrm{n}$ & $t$ & $\mathrm{p}$ & $\mathrm{R}^{2}$ \\
\hline \multicolumn{8}{|c|}{$5 \mu \mathrm{m}$ treatment } \\
\hline Log GRZ & -15.22 & 6.31 & Log HNFi & 9 & 4.37 & 0.003 & 0.732 \\
\hline Log BGRZ & -0.88 & 1.87 & Log B HNFi & 9 & 1.56 & 0.162 & 0.259 \\
\hline Log GRZ & -14.24 & 6.08 & Log HNFi $(\leq 2+2-5)$ & 9 & 4.55 & 0.002 & 0.747 \\
\hline Log BGRZ & -0.76 & 4.62 & Log BHNFi $(\leq 2+2-5)$ & 9 & 2.93 & 0.022 & 0.550 \\
\hline \multirow[t]{2}{*}{ Log GRZ } & -11.76 & 2.21 & Log HNFi $(\leq 2)$ & 9 & 2.45 & 0.049 & 0.702 \\
\hline & & 3.69 & Log HNFi (2-5) & & 3.01 & 0.023 & \\
\hline \multirow[t]{2}{*}{ Log BGRZ } & 1.08 & 2.14 & Log BHNFi $(\leq 2)$ & 9 & 2.40 & 0.053 & 0.695 \\
\hline & & 3.69 & Log BHNFi (2-5 ) & & 3.02 & 0.024 & \\
\hline $\mathrm{NHNF}_{2-5} \mathrm{G}$ & 0.61 & -0.82 & $\mathrm{NHNF}_{5-10} \mathrm{G}$ & 7 & -3.53 & 0.017 & 0.714 \\
\hline \multicolumn{8}{|c|}{$50 \mu \mathrm{m}$ treatment } \\
\hline Log MICRO & 23.40 & -3.28 & $\log \mathrm{BNi}$ & 9 & -2.55 & 0.038 & 0.481 \\
\hline Log BMICRO & 8.60 & -5.82 & Log BBi & 9 & -3.35 & 0.012 & 0.616 \\
\hline Log MICRO & 12.48 & -2.95 & Log HNFi & 9 & -2.84 & 0.025 & 0.536 \\
\hline Log BMICRO & 2.09 & -2.26 & Log BHNFi & 9 & -1.38 & 0.209 & 0.215 \\
\hline \multirow[t]{2}{*}{ Log MICRO } & 11.67 & -2.44 & Log HNFi $(\leq 2+2-5)$ & 9 & -2.48 & 0.047 & 0.600 \\
\hline & & -0.44 & Log HNFi (5-10) & & -1.14 & 0.297 & \\
\hline
\end{tabular}


breakage. The effectiveness of this approach in such a particular system can also be affected by the suspended colloid particles, which slightly reduced bacteria and nanoflagellate abundance in the $5 \mu \mathrm{m}$ relative to the $50 \mu \mathrm{m}$ fraction (Fig. 2). In addition, some HNF larger than $5 \mu \mathrm{m}$ went through the $5 \mu \mathrm{m}$ mesh net, suggesting the importance of the shape of HNF cells on the outcome of differential filtration treatments. For instance, HNF with lengths of 5 to $8 \mu \mathrm{m}$ had widths of 2 to $2.5 \mu \mathrm{m}$. However, we were able to remove large predators in the $5 \mu \mathrm{m}$ filtrate. The size of ciliates and other large protists always exceeded $5 \mu \mathrm{m}$ width, so the $5 \mu \mathrm{m}$-screened treatment was successful in removing these larger predators. Due to the high inorganic nutrient concentration recorded in the ambient and in both treatments after $24 \mathrm{~h}$ incubation (data not shown), the exclusion of large predators probably did not significantly change nutrient regeneration. Despite the inherent limitations of the method, we were able to examine different size-dependent trophic interactions within microbial communities.

\section{Use of FLB for grazing bacterial measurements}

We are aware that heat-killed fluorescent bacteria are perhaps not the best surrogate for measuring protozoan grazing rates. The main concern here is the assumption that they are preyed upon at the same rate as natural bacteria. In fact, we suspect that grazing rates may be underestimated. This is a problem broadly discussed in several review papers, and we will not try to add any new insights here (e.g. Landry 1994, Vaqué et al. 1994).

\section{Microbial dynamics in Johnson's Dock}

This is the first report on temporal changes of planktonic microorganisms in this coastal area, revealing that Johnson's Dock was a peculiar system where water transparency was very poor ( 1.5 m, Secchi disc) due to the glacial flour. A consequence of this 'darkness' was the low chlorophyll concentration found during the study period, in spite of high nutrient concentrations. Copepods were scarce $\left(<100\right.$ ind. $\left.\mathrm{m}^{-3}\right)$; hence, large predators did not presumably deplete phytoplankton growth. Agustí \& Duarte (2000) experimentally induced (using a mesocosm) a large phytoplankton bloom of Thalassiosira antarctica at the same sampling site, when light penetration increased due to sedimentation of colloid material. Diatoms were presumably grazed by a large community of tintinnids (13000 cells $\mathrm{l}^{-1}$ ) and isopods.

\section{Bacterial grazing and production rates}

The total bacterial grazing rates (abundance and biomass) recorded in Johnson's Dock are the highest yet reported for Antarctic waters (Table 4), although specific grazing rates and the impact on bacterial production were rather similar to those found in previous research reports (Table 4 ). The high bacterivory rates in Johnson's Dock may be attributable to the elevated bacterial abundance and biomass there (probably enhanced by the availability of allochthonous organic nutrients carried out by the glacial melting water). This was up to 5- or 10-fold greater than those reported previously for Antarctic waters (Leakey et al. 1996, Ander-

Table 4. Rates of growth, grazing, and percentage of carbon losses to bacterial carbon production in different Antarctic regions during similar sampling periods. nd: not detectable, nr: not reported

\begin{tabular}{|c|c|c|c|c|c|c|}
\hline Month & Site & $\begin{array}{c}\text { Growth rate } \\
\qquad\left(\mathrm{d}^{-1}\right)\end{array}$ & $\begin{array}{l}\text { Grazing rate } \\
\qquad\left(\mathrm{d}^{-1}\right)\end{array}$ & $\begin{array}{c}\text { Carbon loss rate } \\
\left(\mu \mathrm{C}^{-1} \mathrm{~d}^{-1}\right)\end{array}$ & $\begin{array}{l}\% \text { production } \\
\text { grazed }\end{array}$ & Source \\
\hline Dec/Jan & McMurdo Sound & $0.14-0.68$ & $0.04-0.58$ & $\mathrm{nr}$ & $28-86$ & Anderson \& Rivkin (2001) \\
\hline Dec/Jan & McMurdo Sound & $0.00-0.14$ & $<0.0001-0.06$ & $\mathrm{nr}$ & $0.7-5$ & $\begin{array}{l}\text { Moisan et al. (1991), } \\
\text { Putt et al. (1991) }\end{array}$ \\
\hline Dec/Jan & Prydz Bay & $0.57-0.69$ & $0.008-0.13$ & $1.7-4.7$ & $11-36$ & Leakey et al. (1996) \\
\hline Dec/Jan & Antarctic Confluence & 0.44 & $0.22-0.44$ & $\mathrm{nr}$ & $50-100$ & Kuparinen \& Bjorsen (1992) \\
\hline Jan & Ice edge zone & $0.11-0.47$ & nd -0.31 & nd-1.8 & nd -120 & Vaqué et al. (2002b) \\
\hline Jan & Weddell Sea & $-0.40-1.15$ & nd-0.69 & $\mathrm{nd}-4.0$ & nd -120 & Vaqué et al. (2002b) \\
\hline Jan & Bransfield St (FRONT) & $0.12-0.39$ & $0.14-0.31$ & $0.8-2.5$ & $76-119$ & Vaqué et al. (2002b) \\
\hline Jan & Weddell Scotia Confl & $0.21-0.49$ & $0.10-0.40$ & $0.7-4.7$ & $46-109$ & Vaqué et al. (2002b) \\
\hline Dec/Jan & Bellingshausen & $0.11-0.53$ & $0.13-0.26$ & $0.8-1.5$ & $35-100$ & Vaqué et al. (2002a) \\
\hline Dec & Bransfield & $0.08-0.10$ & $0.007-0.14$ & $0.04-1.5$ & $0.5-174$ & Vaqué et al. (2002a) \\
\hline Dec/Jan & Gerlache & $0.05-0.40$ & $0.02-0.25$ & $0.99-1.8$ & $38-80$ & Vaqué et al. (2002a) \\
\hline Dec/Jan & Johnson's Dock $5 \mu \mathrm{m}$ fraction & $0.20-0.71$ & $0.001-0.52$ & $0.09-19.4$ & $1-113$ & This study \\
\hline Dec/Jan & Johnson's Dock $50 \mu \mathrm{m}$ fraction & $0.00-0.89$ & $0.05-0.58$ & $1.2-18.9$ & $22-181$ & This study \\
\hline
\end{tabular}


son \& Rivkin 2001, Vaqué et al. 2002a,b). Indeed, there is evidence that total grazing rates increase as prey increases (Vaqué et al. 1994, 2002b). The highest bacterial losses were observed in late December, consistent with previous reports (Anderson \& Rivkin 2001). This high bacterial consumption (presumably by HNF) did not result in an obvious increase in HNF (after $24 \mathrm{~h}$ ) in the $5 \mu \mathrm{m}$-screened treatment, and particularly in the $50 \mu \mathrm{m}$-screened fraction, where HNF (2 to $5 \mu \mathrm{m}$ ) decreased dramatically. These results suggested an important top-down control on HNF. The prey-topredator ratio (bacteria to HNF abundance) is between 400 and 1000 in most oligotrophic marine waters (Fenchel 1987). High ratios are indicative of strong predator pressure on HNF (Sanders et al. 1992, Gasol 1995). Bacteria-to-HNF abundance ratios reported for the Southern Ocean are rather low (Gerlache Strait, median: 85, Bird \& Karl 1999; Ross Sea, median: 22, Putt et al. 1991; Prydz Bay, median: 142, Leakey et al. 1996), indicative of resource control of HNF abundance. In contrast, the bacteria-to-HNF abundance ratio at community level in Johnson's Dock was high, averaging $625 \pm 109$, and increasing when incubated in the presence of large protists $(1344 \pm 144)$. Topdown control of HNF abundance was particularly high in the $50 \mu \mathrm{m}$-screened fraction, which still showed bacterial mortality (Figs. $2 \& 5$ ).

Our results identify the smallest HNF $(\leq 2$ and 2 to $5 \mu \mathrm{m})$, the most abundant size class, as the main consumers of bacteria (Table 3). The importance of the smallest HNF is consistent with previous reports for the Central Arctic Ocean (Sherr et al. 1997), Polar Front (Selph et al. 2001), Prydz Bay (Leakey et al. 1996), and Gerlache Strait (Bird \& Karl 1999, Vaqué et al. 2002a). Cascading effects in planktonic communities (Calbet et al. 2001) led to the expectation of changes in nano- and picoplankton abundance in the presence of larger nanoflagellates (5 to 10 and 10 to 20 $\mu \mathrm{m})$ and microzooplankton (e.g. ciliates, dinoflagellates). However, those effects were only apparent in the negative relationship between the net HNF growth rate of the 5 to $10 \mu \mathrm{m}$ size class and that of the 2 to $5 \mu \mathrm{m}$ size class (Table 3). Furthermore, it is difficult to establish the details of predator pressure on bacteria due solely to small HNF or to other HNF size classes when larger protists are also present. We expected that the presence of microzooplankton would relieve grazing pressure on bacteria by nanoflagellates; however, this was not the case, as total grazing rates on bacteria remained similar or increased in the presence of microzooplankton. Indeed, ciliates can also be important bacterivores when bacteria are abundant (e.g. $>10^{6}$ $\mathrm{ml}^{-1}$ ), as reported in estuarine and coastal marine systems (Hudson river estuary, Vaqué et al. 1992; George sound, Sherr et al. 1989; Melt ponds of McMurdo ice shelf, James et al. 1995). Hence, large protists could also feed on the abundant bacterial population in Johnson's Dock.

\section{CONCLUSION}

We provide evidence of the complexity of the trophic relationship within the microbial food web in an Antarctic coastal area. High bacterial losses, largely impinged by small HNF were maintained in the presence of their predators, which can also predate on bacteria themselves. Hence, bacteria appear to be a fundamental direct resource for the entire heterotrophic compartment of the microbial food web in the Antarctic coastal area studied.

Acknowledgements. This research was part of the ESEPAC program funded by the Spanish National Antarctic Programme (CICYT ANT97-0273). We thank 'Finis', Víctor Alvà, Óscar Robledo and Luis Gracia for assistance in the field, Clara Cardelús for making helpful comments on the manuscript, Roser Ventosa for analyzing the inorganic nutrients, the personnel of the Spanish Antarctic Base 'Juan Carlos I', especially to M. Castejón and C. Gamboa for support during the study, and the crew of RV 'Hespérides' for assistance on the ship during the trip to Antarctica.

\section{LITERATURE CITED}

Agustí S, Duarte CM (2000) Experimental induction of a large phytoplankton bloom in Antarctic coastal waters. Mar Ecol Prog Ser 206:73-85

Anderson MR, Rivkin RB (2001) Seasonal patterns in grazing mortality of bacterioplankton in polar oceans: a bipolar comparison. Aquat Microb Ecol 25:195-206

Azetsu-Scott K, Syvitski JPM (1999) Influence of melting icebergs on distribution, characteristics and transport of marine particles in an East Greenland Fjord. J Geophys Res 104(C3):5321-5328

Becquevort S (1997) Nanoprotozooplankton on the Atlantic sector of the Southern Ocean during early spring: biomes feeding activities. Deep-Sea Res II 44:355-373

Beers JR, Steward GL (1967) Microzooplankton in the euphotic zone at five locations across the California current. J Fish Res Board Can 24:2053-2068

Bird DF, Karl DM (1999) Uncoupling of bacteria and phytoplankton during the austral spring bloom in Gerlache Strait, Antarctic Peninsula. Aquat Microb Ecol 19:13-27

Børsheim KY, Bratbak G (1987) Cell volume to cell carbon conversion factors for a bacterivorous Monas sp. enriched from seawater. Mar Ecol Prog Ser 36:171-175

Boyd PW, Strom S, Whitney FA, Doherty S, Wen ME, Harrison PJ, Wong CS, Varela DE (1995) The NE subarctic Pacific in winter: I. Biological standing stocks. Mar Ecol Prog Ser 128:11-24

Calbet A, Landry MR, Nunnery S (2001) Bacteria-flagellate interactions in the microbial food web of the oligotrophic subtropical North Pacific. Aquat Microb Ecol 23:283-292

Capriulo GM, Sherr EB, Sherr EF (1991) Trophic behaviour and related community feeding activities of heterotrophic 
marine protists. In: Reid PC, Turley CM, Burkill PH (eds) Protozoa and their role in marine processes. SpringerVerlag, Berlin, p 219-265

Christaki U, Giannakourou A, Van Wambeke A, Gregori G (2001) Nanoflagellate predation on auto- and heterotrophic picoplankton in the oligotrophic Mediterranean Sea. J Plankton Res 23:1297-1310

Fenchel T (1987) Ecology of protozoa-the biology of freeliving phagotrophic protists. Springer-Verlag, Berlin

Gasol JM (1995) A framework for the assessment of top-down vs botttom-up control of heterotrophic nanoflagellate abundance. Mar Ecol Prog Ser 113:291-300

Gasol JM, Moran XAG (1999) Effects of filtration on bacterial activities and picoplankton community structure as assessed by flow cytometry. Aquat Microb Ecol 16: $251-264$

Güde H (1986) Loss processes influencing growth of planktonic bacterial population in Lake Constance. J Plankton Res 8:795-810

Hansen HP, Coroleff F (1983) Determination of nutrients. In: Grasshoff K, Ehrharat M, Kremling K (eds) Methods of seawater analysis, 2nd edn. Verlag Chemie, Weinheim, p 159-228

Harris R, Wiebe P, Lentz J, Skjoldal HR, Huntley M (eds) (2000) ICES zooplankton methodology manual. Academic Press, London

James MR, Pridmore RD, Cummings VJ (1995) Planktonic communities of the melt ponds on the McMurdo Ice Shelf, Antarctica. Polar Biol 15:555-567

Kuparinen J, Bjorsen PK (1992) Bottom up and top-down controls of the microbial food web in the Southern Ocean: experiments with manipulated microcosms. Polar Biol 12: $189-195$

Landry MR (1994) Methods and controls of measuring the grazing impact of planktonic protist. Mar Microb Food Webs 8:37-57

Leakey RJG, Archer SD, Grey J (1996) Microbial dynamics in coastal waters of East Antarctica: bacterial production and nanoflagellate bacterivory. Mar Ecol Prog Ser 142:3-17

Lynn DH, Montagnes DJS (1991) Global production of heterotrophic marine planktonic ciliates. In: Reid PC, Turley CM, Burkill PH (eds) Protozoa and their role in marine processes. Springer-Verlag, Berlin, p 281-307

Marchant HJ, Scott FJ (1993) Uptake of sub-micrometre particles and dissolved organic material by Antarctic choanoflagellates. Mar Ecol Prog Ser 92:59-64

Massana R, Gasol JM, Bjørnsen PK, Blackburn N and 5 others (1997) Measurement of bacterial size via image analysis of epifluorescence preparations: description of an inexpensive system and solutions to some of the most common problems. Sci Mar 61:397-407

Menden-Deuer S, Lessard EJ (2000) Carbon to volume relationships, for dinoflagellates diatoms, and other protist plankton. Limnol Oceanogr 45:569-579

Moisan T, Putt M, Stoecker D (1991) Bacterivory in McMurdo Sound: 2. Information from size fractionation experiments. Antarct J US 26:141-142

Norland S (1993) The relationship between biomass and volume of bacteria. In: Kemp PF, Sheer BF, Sherr EB, Cole JJ (eds) Aquatic microbial ecology. Lewis Publishers, Boca Raton, FL, p 303-307

Pace ML (1988) Bacterial mortality and the fate of bacterial production. Hydrobiologia 159:41-49

Pace ML, McManus GB, Findlay SEG (1990) Planktonic community structure determines the fate of bacterial production in a temperate lake. Limnol Oceanogr 35:795-808

Parsons TR, Maita Y, Lalli CM (1984) A manual of chemical and biological methods for seawater analysis. Pergamon Press, Oxford

Peters F, Marrasé C, Gasol JM, Sala MM, Arín L (1998) Effects of turbulence on bacterial growth mediated through food web interactions. Mar Ecol Prog Ser 172:293-303

Porter KG, Feig YS (1980) The use of DAPI for identifying and counting the aquatic microflora. Limnol Oceanogr 25: 943-948

Putt M, Stoecker DK (1989) An experimentally determined carbon:volume ratio for marine oligotrichous ciliates from estuarine and coastal waters. Limnol Oceanogr 34: 1097-1104

Putt M, Stoecker D, Alsttat J (1991) Bacterivory in McMurdo Sound: 1. Grazing by heterotrophic nanoflagellates. Antarct J US 26:139-140

Salat J, Marrasé C (1994) Exponential and linear estimations of grazing on bacteria: effects on changes in the proportion of marked cells. Mar Ecol Prog Ser 104:205-209

Sanders RW (1991) Trophic strategies among heterotrophic flagellates. In: Patterson DJ, Larsen J (eds) The biology of free-living heterotrophic flagellates. Clarendon Press, Oxford, p 21-38

Sanders RW, Caron D, Berninger UG (1992) Relationship between bacteria and heterotrophic nanoplankton in marine and fresh water: an inter-ecosystem comparison. Mar Ecol Prog Ser 86:1-14

Selph KE, Landry MR, Allen CB, Calbet A, Christensen S, Bidigare RR (2001) Microbial community composition and growth dynamics in the Antarctic Polar Front and seasonal ice zone during late spring 1997. Deep-Sea Res II 48: $4059-4080$

Sherr EB, Sherr BF (1994) Bacterivory and herbivory: key roles of phagotrophic protists in pelagic food webs. Microbiol Ecol 28:223-235

Sherr EB, Sherr BF (2002) Significance of predation by protists in aquatic microbial food webs. Antonie Leeuwenhoek 81:293-308

Sherr BF, Sherr EB, Pedrós-Alió C (1989) Simultaneous measurement of bacterioplankton production and protozoan bacterivory in estuarine water. Mar Ecol Prog Ser 54: 209-219

Sherr EB, Sherr BF, Fesenden L (1997) Heterotrophic protists in the central Arctic Ocean. Deep-Sea Res II 44:1665-1682

Sieracki ME, Johnson PB, Sieburth JMcN (1985) Detection, enumeration and sizing of planktonic bacteria by image analyzed epifluorescence microscopy. Appl Environ Microbiol 49:799-810

Simon M, Azam F (1989) Protein content and protein synthesis rates of planktonic marine bacteria. Mar Ecol Prog Ser 51:201-213

Stoecker DK, Gifford DJ, Putt M (1994) Preservation of marine planktonic ciliates: losses and cell shrinkage during fixation. Mar Ecol Prog Ser 110:293-299

Vaqué D, Pace ML, Findlay SEG, Lints D (1992) Fate of bacterial production in an heterotrophic ecosystem: grazing by protist and metazoans in the Hudson estuary. Mar Ecol Prog Ser 89:155-163

Vaqué D, Gasol JM, Marrasé C (1994) Grazing rates on bacteria: the significance of methodology and ecological factors. Mar Ecol Prog Ser 109:263-274

Vaqué D, Guixa-Boixereu N, Gasol JM, Pedrós-Alió C (2002a) Distribution of microbial biomass and importance of protists in regulating prokaryotic assemblages in three areas close to the Antarctic Peninsula in spring and summer 1995/96. Deep-Sea Res II 49:847-867

Vaqué D, Calderón-Paz JI, Guixa-Boixereu N, Pedrós-Alió C (2002b) Spatial distribution of microbial biomes and activ- 
ity (bacterivory and bacterial production) in the northern Weddell sea during the Austral summer (January 1994). Aquat Microb Ecol 29:107-121

Vazquez-Dominguez E, Peters F, Gasol JM, Vaqué D (1999) Measuring the grazing losses of picoplankton. Methodological improvements to the use of fluorescently labeled tracers combined to flow cytometry. Aquat

Editorial responsibility: John Dolan, Villefranche-sur-Mer, France
Microb Ecol 20:111-128

Verity PG, Langdon C (1984) Relationships between lorica volume, carbon, nitrogen and ATP content of tintinnids in Narragansett Bay. J Plankton Res 6:859-868

Wikner J, Hagström Å (1988) Evidence for a tightly coupled nanoplanktonic predator-pry link relating the bacterivore in the marine environment. Mar Ecol Prog Ser 50:137-145

Submitted: October 7, 2003; Accepted: February 27, 2004 Proofs received from author(s): June 2, 2004 